\title{
SISTEM PAKAR DIAGNOSA PENYAKIT PADA BURUNG KENARI DENGAN METODE CERTAINTY FACTOR
}

\author{
Ari Rahmawati ${ }^{1}$, Dwi Puspitasari ${ }^{2}$, Hendra Pradibta ${ }^{3}$ \\ ${ }^{123}$ Program Studi Teknik Informatika, Jurusan Teknik Elektro, Politeknik Negeri Malang \\ 1arirahmawati16@gmail.com, ${ }^{2}$ dwi.istari@gmail.com, ${ }^{3}$ ndropradibta@yahoo.com
}

\begin{abstract}
Abstrak
Burung kenari banyak diminati, maka dalam pemeliharaannya diperlukan informasi yang tepat. Salah satu informasi yang diperlukan adalah solusi penanganan terhadap penyakit burung kenari. Saat ini solusi penanganan penyakit hanya didapatkan dari dokter hewan sehingga untuk mempermudah pemilik burung kenari mendapatkan informasi diagnosa penyakit dan solusi penyakit pada burung kenari.Untuk mengatasi permasalahan tersebut maka diperlukan sebuah sistem pakar diagnosa penyakit pada burung kenari dengan metode Certainty Factor(CF) agar didapatkan keakuratan atau ketepatan perhitungan dalam mendiagnosis gejala penyakit pada burung kenari. Sistem ini dikembangkan dengan menganalisis gejala-gejala penyakit yang diinputkan kemudian diolah dan diperhitungkan dengan CF. Hasil diagnosa sistem menampilkan penyakit yang diderita burung kenari dan memberikan solusi pada penyakit dengan nilai prosentase certainty factor terbesar.
\end{abstract}

\section{Kata kunci : burung kenari, Certainty Factor (CF), sistem pakar}

1. Pendahuluan

Burung Kenari (Serinus Canarius) adalah burung yang pertama ditemukan oleh Pelaut Prancis Jean de Berthan Cout di Kepulauan Canary pada abad XV. Burung kenari banyak diminati oleh banyak orang, baik untuk budidaya maupun untuk dipelihara. Hal ini dikarenakan burung kenari memiliki keindahan bulu, memiliki suara yang merdu dan sangat beragam di alam. Oleh karena hal tersebut, burung kenari memiliki nilai ekonomi yang tinggi dan sering dijadikan objek dalam perlombaan burung. Selain dapat dijadikan sebagai hobi, memelihara burung kenari juga berpotensi memberikan peluang usaha yang ringan, mudah, murah dan menghasilkan keuntungan yang cukup besar.

Salah satu kelemahan dari budidaya maupun pemeliharaan burung kenari adalah sangat rentan terhadap penyakit. Penyakit yang mungkin menyerang burung kenari, misalnya penyakit yang disebabkan virus circovirus (Beak and Feather Disease) dan virus polyoma. Penyakit tersebut dapat menyebabkan burung kesulitan memproduksi bulu. Gangguan dari parasit dan infeksi bakteri pada usus juga dapat menghambat pertumbuhan burung kenari. Selain itu, asupan gizi yang kurang, penggunaan bahan kimia yang tidak cocok dengan kondisi fisiologis burung kenari, adanya perbedaan cuaca dan kondisi sangkar yang kurang bersih juga dapat berpengaruh terhadap kesehatan dan pertumbuhan burung kenari (Sudrajat, 2000; Klub Burung, 2014).

Upaya yang telah dilakukan untuk mengatasi permasalahan tersebut adalah dengan 1) memberikan perawatan harian dan perawatan khusus secara berkala, bagi burung kenari yang dipelihara pribadi atau yang diikutkan lomba; 2) menempatkan burung kenari dalam sangkar yang dibuat berdasarkan standar ukuran dan kriteria sangkar yang baik; 3) memberikan pakan dengan menu variatif sehingga kebutuhan nutrisi (protein dan karbohidrat), vitamin (vitamin A, D3, E, B1, B2, B3 (Nicotimanide) B6, B12, C dan K3), mineral dan zat-zat esensial seperti D-L Methionine, I-Lisin Hcl, Folid Acid dan Ca-D dapat terpenuhi dengan baik. Keberhasilan upayaupaya tersebut faktanya memerlukan biaya yang besar dan masih sangat bergantung pada tenaga ahli (Klub Burung, 2014). Dengan demikian, perlu problem solving yang lebih mudah, murah dan efisien untuk mendeteksi gangguan kesehatan yang dialami oleh burung kenari. Salah satu alternative untuk mengatasi masalah tersebut adalah dengan memanfaatkan teknologi berupa media konsultasi yang dapat diakses oleh pemilik burung kenari yang sifatnya online.

Teknologi informatika yang dimaksud telah mencakup bidang kedokteran. Salah satu cabang ilmu komputer yang dapat mendukung hal tersebut adalah sistem pakar. Sistem pakar (Expert System) merupakan salah satu cabang kecerdasan buatan yang mempelajari bagaimana cara seseorang pakar berfikir dan bernalar dalam menyelesaikan dan membuat keputusan. Dasar dari suatu sistem pakar adalah bagaimana mentransfer pengetahuan yang dimiliki oleh seorang pakar kedalam komputer. Sistem pakar ini diharapkan bisa membantu pemilik burung kenari mendapatkan informasi diagnosis penyakit tersebut, sehingga dapat memperkecil resiko kesalahan dalam proses mendiagnosa penyakit pada burung kenari.

Pemenuhan konsep sistem pakar dengan basis pengetahuan dilakukan dengan pengumpulan data dan informasi terkait jenis penyakit pada burung 
kenari, dengan studi pustaka dan konsultasi dengan dokter hewan sebagai pakar. Konsep inference engine dilakukan dengan penilaian bobot menggunakan Certainty Factor (CF).

Menurut Giarratano dan Riley dalam Latumakulita (2012), sistem pakar harus mampu bekerja dalam ketidakpastian. Sejumlah teori telah ditemukan untuk menyelesaikan ketidakpastian, antara lain:

a. Probabilitas klasik (classical probability).

b. Probabilitas Bayes (Bayesian probability).

c. Teori Hartley berdasarkan himpunan klasik (Hartley theory based on classical sets).

d. Teori Shannon berdasarkan pada probabilitas (Shanon theory base on classical).

e. Teori Dempster-Shafer (Dampster-Shafer theory).

f. Teori fuzzy Zadeh (Zadeh's fuzzy theory).

Berhubungan dengan teori-teori tersebut Kusrini (2008), menambahkan bahwa faktor kepastian atau certainty factor (CF) juga dapat digunakan untuk merancang sistem pakar, sehingga dapat menyelesaikan ketidakpastian. Perancangan sistem pakar dengan memanfaatkan metode tersebut diharapkan bisa menafsirkan kondisi kesehatan burung kenari. Prinsip dasar metode tersebut adalah menyatakan kepercayaan dalam sebah kejadian (fakta atau hipotesis) berdasarkan bukti atau penilaian pakar. Certainty Factor (CF) dapat terjadi dengan berbagai kondisi. Diantara kondisi yang terjadi adalah terdapat beberapa aturan yang berbeda dengan konsekuen yang sama.

Variasi genetik yang merefleksikan adanya variasi respon intraspesies burung kenari terhadap lingkungan, secara langsung mempengaruhi perubahan atau tipe adaptif masing-masing spesies burung kenari. Hal tersebut secara tidak langsung menuntut pemelihara dan pemilik burung kenari membutuhkan informasi yang tepat tentang kesehatan burung kenari. Oleh sebab itu, pada penelitian ini dilakukan studi lebih lanjut tentang bagaimana rancangan sistem pakar menggunakan metode CF dan berbasis Web. Dengan demikian, diharapkan sistem pakar yang dihasilkan dapat membantu para user (pemeliharan atau pemilik burung kenari) mendapatkan informasi yang lengkap dan tepat tentang kondisi kesehatan atau penyakit burung kenari. Diagnosis awal tersebut penting karena akan menentukan diagnosis lanjutan dan penangan yang tepat yang dilakukan oleh para dokter hewan.

\section{Metode}

\section{Physical Design \\ Work Breakdown Structure}

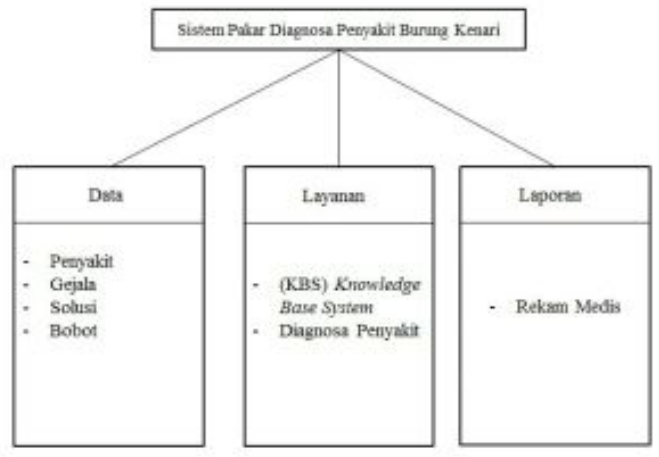

Gambar 2.2 Work Breakdown Structure

\section{ERD (Entity Relationship Diagram)}

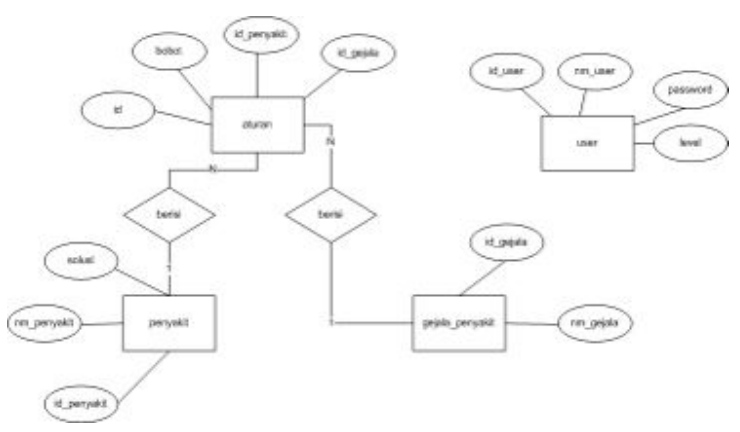

Gambar 2.3 Entity Relationship Diagram

Adapun rumusan dasar dari Certainty Factor (Sutojo, 2011) sebagai berikut:

a. Metode 'Net Belief' yang diusulkan oleh Shortliffe dan Buchanan yaitu:

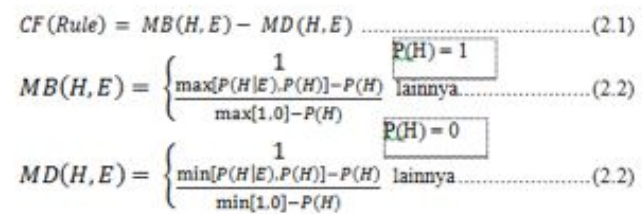

Keterangan:

CF(Rule)

: faktor kepastian

$\mathrm{MB}(\mathrm{H}, \mathrm{E})$

: measure of belief (ukuran kepercayaan) terhadap hipotesis $\mathrm{H}$, jika diberikan evidence $\mathrm{E}$ (antara 0 dan 1)

$\mathrm{MD}(\mathrm{H}, \mathrm{E}) \quad$ : measure of disbelief (ukuran ketidakpercayaan) terhadap evidence $\mathrm{H}$, jika diberikan evidence $\mathrm{E}$ (antara 0 dan 1)

: probabilitas kebenaran
hipotesis $\mathrm{H}$


$\mathrm{P}(\mathrm{H} \mid \mathrm{E})$

: probabilitas bahwa $\mathrm{H}$ benar karena fakta $\mathrm{E}$

b. Dengan cara mewawancarai seorang pakar Nilai CF (Rule) didapat dari interpretasi "term" dari pakar, yang diubah menjadi nilai CF tertentu sesuai tabel berikut:

Tabel 1. Nilai CF Interpretasi

\begin{tabular}{|c|c|}
\hline Uncertain Term & CF \\
\hline Defanitely not (pasti tidak) & -1.0 \\
\hline Almost catainly not (banypir tidak pasti) & 0.8 \\
\hline Protably not (kemungkinan besas tidak) & -0.6 \\
\hline Maybe no: (mungkin tidak) & -0.4 \\
\hline Unknown (tidak tahu) & -0.2 tc 0.2 \\
\hline Maybe (manpkia) & 0.4 \\
\hline Protably (kemungkinan besar) & 0.6 \\
\hline Almost certainly (hxmpir pasti) & 0.8 \\
\hline Definitely (pasti) & 1.0 \\
\hline
\end{tabular}

Suatu sistem pakar seringkali memiliki kaidah lebih dari satu dan terdiri dari beberapa premis yang dihubungkan dengan $A N D$ atau $O R$. Formula Certainty Factor untuk beberapa kaidah yang mengarah pada hipotesa yang sama menurut Kusrini (Latumakulita, 2012), dapat dituliskan sebagai berikut :

$$
C F(H)=\left\{\begin{array}{cl}
C F(R 1)+C F(R 2)-[C F(R 1) * C F(R 2)] ; & \text { Nilai } C F(R 1) \operatorname{dan} C F(R 2)>0 \cdots \ldots \ldots . .(2) \\
C F(H) C F(R 1)+C F(R 2)+[C F(R 1) \times C F(R 2)] ; & \text { Nilai } C F(R 1) \operatorname{dan} C F(R 2)<0 \\
\frac{C F(R 1)+C F(R 2)}{1-\min [(C F(R 1) ! C F(R 2)] ;} ; & \text { Nilai } C F(R 1) \operatorname{dan} C F(R 2) \text { berlawanan tanda }
\end{array}\right.
$$

Konsep user interface dikembangkan dengan pembuatan antarmuka yang user friendly sehingga memudahkan dalam pengisian data dan fakta. Keluaran yang disajikan berupa informasi nilai kepercayaan jenis penyakit yang menyerang, sedangkan uji validitas hasil diagnosis dikomparasi dengan pakar. Selain itu, pengembangan dan pembangunan aplikasi digunakan dengan PHP dan MySQL sebagai tools language dalam konstruksinya.

Berdasarkan pengetahuan yang diperoleh dari pakar maka dibangun tabel keputusan sebgai dasar pembuatan mesin inferensi. Tabel keputusan seperti pada tabel 1. Nilai Certainty Factor (CF) ditentukan untuk setiap gejala pada penyakit dan dalam sistem ini nilai dapat diupdate.

Tabel 2. Tabel Keputusan Gejala Penyakit

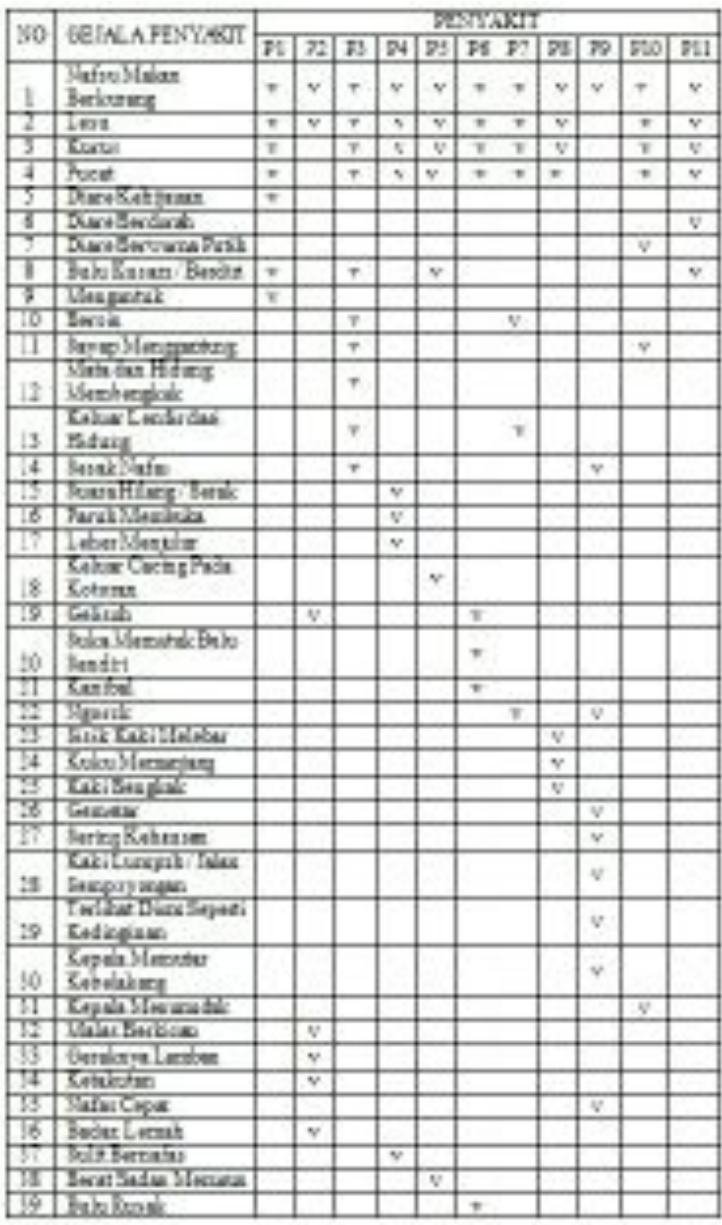

Keterangan penyakit:

P1: Fowl Typhoid, P2: Setres, P3: Snot, P4: Aspergillosis, P5: Cacing (Endoparasit), P6: Kutu (Ektoparasit), P7: CRD/ Ngorok, P8: Bubul, P9: Tetelo, P10: Berak Kapur (Salmonellosis), P11: Berak Darah (Coccidiosis).

\section{Hasil}

Bahasa pemrograman yang digunakan dalam membangun sistem ini adalah Hypertext Preprocessor (PHP). Untuk dapat melakukan pengelolahan data pengetahuan berupa data penyakit dan rule maka pakar harus terlebih dahulu melakukan proses login untuk memastikan user tersebut sebagai pakar. Berikut merupakan tampilan yang telah dibuat:

\section{Halaman Login}

Halaman ini adalah halaman yang dikhususkan untuk seorang pakar sebelum memasuki halaman pakar.

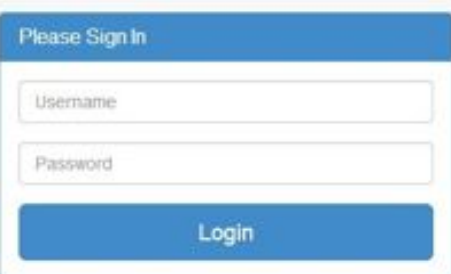

Gambar 3.1 Tampilan Halaman Login 


\section{Halaman Pakar}

Gambar berikut ini adalah tampilan halaman daftar penyakit burung kenari.

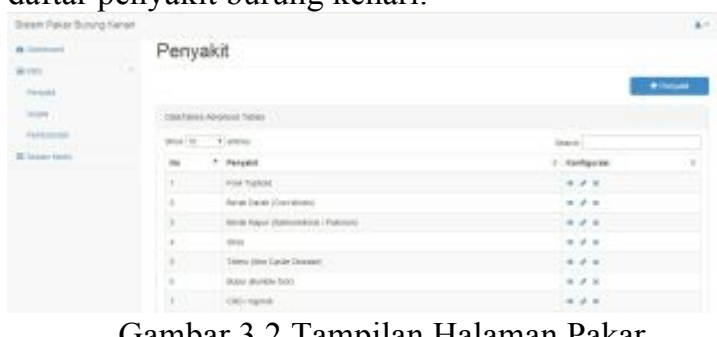

Gambar 3.2 Tampilan Halaman Pakar

Form Konsultasi User

Gambar berikut ini adalah tampilan form konsultasi user.

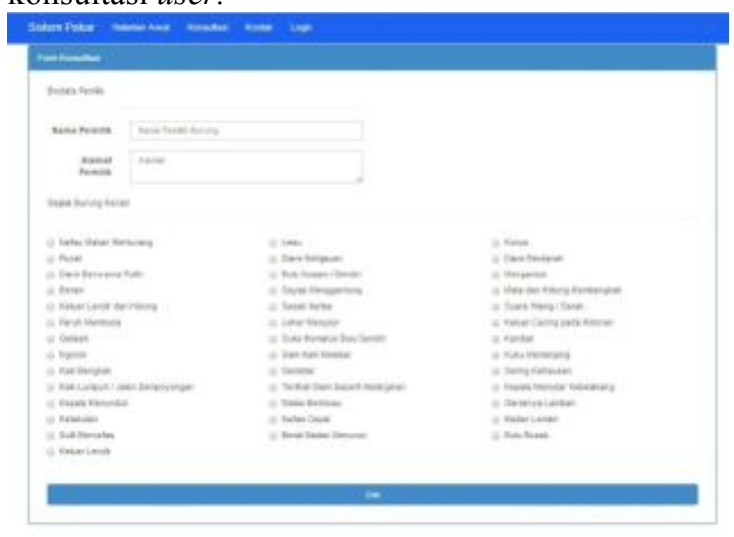

Gambar 3.3 Tampilan Konsultasi User

\section{Halaman Hasil Diagnosa}

Gambar dibawah ini merupakan hasil diagnosa perhitungan dari certainty factor.

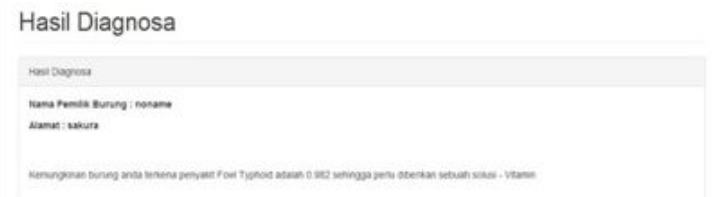

Gambar 3.4 Tampilan Hasil Diagnosa

\section{Pembahasan}

Dengan menggunakan rumus 2 nilai $\mathrm{CF}$ untuk setiap penyakit dihitung kemudian ditampilkan jenis penyakit dengan nilai CF terbesar. Gejala-gejala yang dipilih antara lain:

- Sayap Menggantung

- Mengantuk

- $\quad$ Suara Hilang / Serak

- Kuku Memanjang

- Bulu Rusak

Nilai CF masing-masing gejala ditiap penyakit adalah sebagai berikut:
Tabel 3. Tabel nilai CF gejala yang dipilih

\begin{tabular}{|l|c|c|c|c|c|}
\hline Gejala & P01 & P03 & P06 & P08 & P10 \\
\hline G09 & 0.6 & & & & \\
\hline G11 & & 0.6 & & & \\
\hline G15 & & & & & 0.8 \\
\hline G24 & & & 0.7 & & \\
\hline G39 & & & & 0.5 & \\
\hline
\end{tabular}

R1 = IF Mengantuk THEN Fowl Typhoid

R2 = IF Sayap Menggantung THEN Berak Kapur

R3 = IF Kuku Memanjang THEN Bubul

R4 = IF Bulu Rusak THEN Kutu

R5 = IF Suara Hilang / Serak THEN Aspergillosis

Dari aturan diatas dapat masukkan pada rumus CFkombinasi $=\mathrm{CF}(\mathrm{R} 1)+\mathrm{CF}(\mathrm{R} 2)-(\mathrm{CF}(\mathrm{R} 1) * \mathrm{CF}(\mathrm{R} 2))$, berikut perhitungan CFkombinasi sesuai rumus diatas:

CFkombinasi $(1)=0.6$

CFkombinasi $(2)=0.6$

CFkombinasi $(3)=0.7$

CFkombinasi $(4)=0.5$

CFkombinasi $(5)=0.8$

Dari perhitungan diatas terdapat nilai tertinggi yaitu pada rule ke5 yaitu Aspergillosis.

\section{Simpulan dan Saran} Simpulan

Berdasarkan perancangan, implementasi dan uji coba sistem pakar diagnosa penyakit pada burung kenari dengan metode certainty factor, maka didapatkan kesimpulan sebagai berikut :

1. Salah satu cara mendiagnosa penyakit burung kenari berdasarkan gejala yang dialami, dapat dilakukan menggunakan sistem pakar dengan metode Certainty Factor.

2. Sistem pakar yang dikembangkan memiliki data dari seorang dokter hewan. Untuk mendapatkan solusi yang tepat dalam menangani penyakit burung kenari dengan melakukan konsultasi menggunakan sistem pakar yang telah dikembangkan dan memiliki hasil prosentase sebesar $99 \%$.

\section{Saran}

Untuk pengembangan lebih lanjut sistem ini dapat dibandingkan permasalahan dan metode yang lain.

\section{Daftar Pustaka}

Arief, M. Rudyanto (2011), Pemrograman Web Dinamis menggunakan PHP dan MySQL, Yogyakarta : Andi.

David Poole dan Alan Mackworth (2010), Artificial Intelligence: Foundations of Computational Agents. Cambridge University Press. 
Kusumadewi, Sri (2009), Artificial Intelligence (Teknik dan Aplikasinya) Graha Ilmu : Yogyakarta.

Kusrini (2008), Aplikasi Sistem Pakar. Yogyakarta: Andi.

Latumakulita, L A, (2012), Sistem Pakar Pendiagnosa Penyakit Anak Menggunakan Certainty Factor $(C F)$. Universitas Sam Ratulangi, Manado.

Muhannad, Arhami (2010), Konsep Dasar Sistem Pakar, Yogyakarta : Andi.

Rohajawati, Siti dan Supriyati, Rina (2010), Sistem Pakar: Diagnosis Penyakit Unggas Dengan Metode Certainty Factor. Universitas Pakuan, Bogor.
Sudradjat, (2000), Merawat dan Melatih Kenari Fusan. Penebar Swadaya: Jakarta.

Sutojo, T., Mulyanto, Edy, dan Suhartono, Vincent (2011), KECERDASAN BUATAN, Penerbit Andi, Yogyakarta, Universitas Dian Nuswantoro Semarang, Semarang.

http://kenariku.tripod.com, Penyakit Kenari, tanggal akses: 31 Januari 2014.

http://omkicau.com, Kenari, tanggal akses: 28 Juni 2014.

http://download.portalgaruda.org, Hoby Kenari Bisa Jadi Usaha Ringan, Murah, dan Menguntungkan, tanggal akses: 29 Juni 2014. 